Review Article

UDC: 615.47(497.11) ; 069.51:615.47(497.11)

ID BROJ: 202543372

Ivana Ćirić

PhD Candidate, Department of Art History

Faculty of Philosophy, University of Belgrade

Čika Ljubina 18-20, 11000 Belgrade, Serbia

ivana.ciric@f.bg.ac.rs

\title{
MAJOR MUSEUM COLLECTIONS OF MEDICAL INSTRUMENTS IN BELGRADE
}

\begin{abstract}
The leading vision of the paper is to present existing medical instruments among the Belgrade museums collections. Therefore, five museums and theirs collections of medical instruments will be displayed followed by brief explanations. The origins of medical practice can be traced in several ways: written sources, the legacy of art, and escavated medical objects. In order to present several objects dated in $1^{\text {st }}$ - $4^{\text {th }}$ century, author examines the medicine practice in the territory of former Upper Moesia (Moesia Superior) and Pannonia Inferior, then Ager Singidunensis and Kosmaj area. Along side, the medical apparatus from recent medical history are also shortly presented. Some examples are accompanied by photos or draws.
\end{abstract}

Keywords: instruments, museum, history of medicine Non MeSH: museum collections

Ključne reči: instrumenti, muzej, istorija medicine $\mathrm{Ne} \mathrm{MeSH}$ : muzejske kolekcije 
The Belgrade City Museum holds several prominent antique collections consisting of medical instruments dating from the $1^{\text {st }}$ to the $4^{\text {th }}$ century CE. They were found (with a few exceptions) within a territory in the jurisdiction of the Belgrade City Museum and the National Museum in Belgrade. The geographic origins of these objects include two provinces, the former Upper Moesia (Moesia Superior) and Pannonia Inferior then Ager Singidunensis and Kosmaj area - where Roman metal mines [10, p11] as well as one of the largest silver mine were located. [10, pp13-14] The most important city of Moesia was Singidun with its surrounding lands, which was conquered by Romans, starting in the $1^{\text {st }}$ century BC. Moesia was formally organized into a province later on, around $6 \mathrm{CE}$, when its governor Caecina Severus was first mentioned. This was the time when the name - Singidun was romanized and changed to Singidunum. The city was an important strategic place along Via Militaris, a Roman road that linked the settlements and forts along the Danube limes until the fifth century. Singidunum reached its peak by arriving of the Legion IV Flavia Felix around $86 \mathrm{CE}$ when Moesia was divided into two provinces.

This legion built a square castrum (fort), [10,p18] located in the Upper Town (today's Kalemegdan). The fortress was an important military checkpoint [11,pp16-17] surrounded by craft workshops. [10,p19] [12] Facts speak for the importance of Singidunum - Legion camp, which was among the largest in Upper Moesia. [3,p304] The area now known as Student Square was surrounded by thermae, [10,p18] necropolis was scattered widely around the Kalemegdan fortress, and the Fortress well, water pipes stretching along an area known today as Vračar as well as pottery and coins were found. [11,p17] During the reign of the emperor Hadrian, in the middle of the $2^{\text {nd }}$ century, Singidunum gained a status and privileges of a municipio (municipium) and during the first half of the third century it became a colony. [13,p80]

The establishment of the Roman legions in the territory of Singidunum caused urbanization in various aspects in the society of the time. Revealed medical and pharmacological instruments such as forceps, probes, scalpels, special knives, and others, have shown that there were medicus [14] in Singidunum who took care about the health of its residents. The profession of Medicus also implied knowledge of pharmacology, making medicines, and aromatic balsams. [14, 15, 16,p4, 17] A stamp of an ophthalmologist, [14] discovered in the Lower Town of Kalemegdan, and gravestones of deceased doctors from the territory of Upper Moesia, reliably confirm the presence of various medical services in the territory of the Roman Singidunum. [17] 
However, as a profession, medicine in ancient Roman Society was far less appreciated then in ancient Greece. Doctors were freed Greek slaves, enjoying some esteem among their customers. Hence, the social standing of doctors was quite low. Because recovery rates were so low and there were no formal requirements for entrance to the profession, many people were skeptical. Medical training consisted mostly of apprentice work and anyone could call himself a doctor especially if his methods were mostly successful.

Large numbers of instruments in the collection "certainly confirms the presence of doctors with different titles: archiatri populares (municipal doctors), medicus chirurgus (surgeon), medicus clinicus (doctor in hospital), medicus ocularius (oculist) and others". $[10, \mathrm{p} 240]$

The best surviving examples of the tools at a surgeon's disposal in the $1^{\text {st }}$ century BC from which we can see the actual look of surgical tools used in Ancient Rome are excavated from The House of the Surgeon at Pompeii. "Since there was relatively little innovation in surgery and surgical tools from the time of Hippocrates $\left(5^{\text {th }}\right.$ century BC.) and Claudius Galen ( $2^{\text {nd }}$ century CE.), this collection is typical of surgical practice for nearly a millenium..”. [18] (Photo Picture 2)

The discovered instruments are the best analogy for establishing and comfirming the origins of ancient Roman medical instruments in the collections from the Belgrade City Museum and The National Museum in Belgrade. Most of the instruments were very similar to those used today; the biggest change is in the materials from which they are made of.

The medical instruments from Antique collections in the Belgrade City Museum are made of stone, silver and bronze, with the techniques of casting, engraving and cutting. These instruments originate from $2^{\text {nd }}-3^{\text {rd }}$ century BC. [14] Preciousness and durability of bronze as well as other possibilities of its manufacture [10,p8,21] made it very popular in the Ancient Rome. Basic techniques for making bronze objects were casting and forging. In this maner a few instruments from the above mentioned collection were made from: five probes, two pincers (vulsella), two spoons, shears, two scalpels (scapellus) and a double purpose instrument. [10,pp240-243] 
Probes were widely spread instruments, commonly used in medicine and pharmacy. Probes from the collection are consisted of long handle and while two probes have spatula-shaped upper part, the others have olive-shape instead. The termination of probes is in the shape of olive or point. Among those are three simple probes (auriscalpium) used for various purposes. It is assumed that longer auriscalpia were used in medicine while others were used in pharmacology and cosmetology.[10,p241] The longest probe is $15,8 \mathrm{~cm}$ and the smallest one 5,9 cm long. Additional instruments were also widely used in different purposes.

Both pincers from the collection have blunt ends and rounded head and they are around $5 \mathrm{~cm}$ long.

Spoons were used in different occasions including measuring and heating of medicaments. [10,p241] These collections possess two spoons; one of them 14,4 cm long and the other one $15,5 \mathrm{~cm}$ long. One type of shears has $10.1 \mathrm{~cm}$ in length; its escavation site is still unknown. It is included into this collection as well; these shears are $10.1 \mathrm{~cm}$ long.

Scalpel was as it is today, the most basic instrument for every doctor, especially when it comes to surgery. They were used for delicate and precise cuts. The two scalpels from the collection are $7.3 \mathrm{~cm}$ and $6.1 \mathrm{~cm}$ long. They were made as knives with leaflike blades and square-shaped handles. Scalpels usually had an oval or triangular scoop, which is missing on these two speciments. One of the two was decorated with silver encrusting. [10,p240] It has been assumed for a long time that the leaf-shape part is a scalpel blade too. But, this part was forged all together with the handle and did not contain sharp enough edges. Furthermore, it was obvious that some parts are missing (due to pieces that were striking out of a handle part). Recent researches have proven that the missing part was particularly used for cutting tissue and for deeper penetration into the tissue. With most instruments detected with a slot or slit for inserting special iron pins (which were able to be removed and replaced) at the other end of the handle, scientists concluded that what was considered to be a blade-shaped leaves, was never used for cutting wounds but instead used for treat and healing. Therefore, we can conclude that the Roman scalpel was a dual-purpose instrument. [10,p240, 17]

Double purpose instrument (stilus) is $12,5 \mathrm{~cm}$ long with flat upper part, $1 \mathrm{~cm}$ wide, have pointed end and it is supposed that it was used for teeth extraction. 
The National Museum in Belgrade has two collections (Dunjic and Kosmaj) containing medical instruments. $[19,20]$ The collections include items from legacy Dunjic and objects escavated from Kosmaj necropolis originating from $1^{\text {st }}$ to $4^{\text {th }}$ century B.C. The collections are very similar and it is commonly thought, that these collections could give us better understing of the role which Kosmaj and its surroundings had in Roman society. [10,p17,21, 19] [20,21]

Two knives from the collection are different shapes and sizes and had different purposes. One of them is with long handle and has beaten blade surface. [10,p240] It was used for scull trepanation. [16,p5, 22, 23] An overall length of this knife is $16 \mathrm{~cm}$. The other one is $19 \mathrm{~cm}$ long and it was used for ophthalmological purposes. It has a long handle, decorated in the upper section and it ends with leaf-like shape with cutting edge on both side. [10, p240]

Four probes from the collections are very similar to ones previously described (situated in The Belgrade City Museum collection) - one auriscalpium (13,7 cm length), one specillum oricularium (13,4 cm length), one spathomela - acus (15,6 cm length) (Draw 1) and cyathiscomela (17,4 length). [10,p241]

Double purpose instrument (stilus) from this collection is $13,9 \mathrm{~cm}$ long with flat upper part and 0,9 $\mathrm{cm}$ wide having a very pointed end. (Draw 2)

The next instrument is a pincer, $8 \mathrm{~cm}$ long. It was accidentally found in Grocka and it is very similar to nowadays pincers. [10,p241]

Within the Museum of Science and Techology there is a special department - The Museum of Serbian Medical Society. Since 2007 The Museum of the Serbian Medical Society has been a part of the Museum of Science and Technology. Its first permanent exhibition was opened on $27^{\text {th }}$ March 2012. Within the exhibition "Medicine in Serbia through centuries" items collected under Serbian Medical Society since 1872 have been presented covering the period from the late Paleolithic period to the present day. The oldest artifact in the exhibition is a fracture treated ulna of Cro-Magnon, estimated at 7,000 years old. [24] Besides, there are some medical instruments escavated from Viminacium which originate from $1^{\text {st }}$ and $2^{\text {nd }}$ century CE. (Photo Picture 3) A few displayed scrapers (Photo Picture 4) we can also considered to be a sort of medical instrument due to its purpose to remove the excess of oil from the skin of athlets after the training. [25] 
The other interesting medical objects within exhibition of a fairly recent age will be shortly examined and presented in the next chapter.

The history of medicine and development of diverse instruments can be traced in two different ways. Archaeologically - by written sources as well as by the physical shape of instruments and Anthropologically - based on skeletal remains. The objects from the collections described, indicates, undoubtedly, the existence of diseases and treatments on the teritory of Serbia 2000 years ago. For further tracking of these occurrences, escavations in Viminacium are of particular importance. During the last few decades, 1300 skeletal remains were escavated along with different objects burried alongside. [16, 22, 23] By the conditions of bones a couple of things were observed. There were some wounds and diseases that were neglected or not treated at all, thus indicating social stratification in terms of medical care, or intervention of low-skilled doctor. Needless to say, parallel existence of higly professional rehabilitated injuries indicate the existence of highly skilled doctors. Therefore we can conclude that medicine was well-developed at that time and that some surgeons skillfully used different blades and instruments when performing.

The collection - Medical Technology - from the Museum of Science and Technology, holds in fifty two items belonging to various fields of medicine. It was formed entirely of gifts and the biggest donor was the Institute of Pathophysiology at the Faculty of Medicine in Belgrade. Those are mostly ophthalmologic instruments and their production date can be traced from 1927 onwards. The oldest item is an X-ray cabinet from 1927. It is worth mentioning also a dental office that was purchased in Paris in 1936. [26]

The biggest part of permanent collection Medicine in Serbia through centuries (within The Museum of the Serbian Medical Society) are medical apparatus and instruments dated from $19^{\text {th }}$ century onwards. The content from the $19^{\text {th }}$ century Medical Bag (Photo picture 5) reveals the common medical accessories at the time: nozzle (made of plated brass), pocket surgical supplies, bandages... Some of them are no longer in use because they are not suitable for sterilization. Next interesting item is the first instrument for embryo transfer, patented during the 1970's by doctor Petar Radović. Unfortunately, this patent was never tested and the Nobel Prize in the field of artificial insemination went to doctor Robert Edwards in 2010. [25] Long bones fixator, gynecological apparatus, gas masks from the First World 
War, the invention of anesthesia and X-rays and many other instruments, accompanied by document and pictures shows the level of achievements of medicine in our country.

This brief display would not be complete without mentioning maybe the precious ones and certainly the unique medical instruments preserved amoung the Electrical collection in the Nikola Tesla Museum. These instruments for the high-frequency treatment originate from the beginning of $20^{\text {th }}$ century. Within this collection there are two such instruments. While one is complete the other is missing parts. It is assumed that this was a prototype and that there were more then a few models of this instrument. Instrument is preserved in original wooden box along with fabric paneling on the inside part of the box. Further information about it cannot be traced, because it is still under research. As we know, instruments with similar functions were used in medical practice during the $19^{\text {th }}$ century. These instruments were expensive and bulky and there were no evidence of their benefits so they went out of use.

\section{Conclusion}

By presenting some medical instruments within the Belgrade museums collections we could clearly observe and conclude that the migration of people and cultures had great influence on development of medicine. We can also conclude that there was a time in history when medicine was treated as a practice (dealing with the treatment) and that there was a time when it was considered to be a science. [1] Nowadays medicine use acquired experience of centuries and combines the two approaches. Although we can confirm the advances and breakthroughs of medicine, the same thousand year old diseases still exist. Perhaps this journey forward is actually just a small step at the wheel of history which repeats itself. The fact is that we know a little about the medicine of ancient pyramid builders and it may be that they had brought with them greater secret than we can imagine. Therefore, we must not neglect the study of medical history because it may give us a remarkable revelation if we find out that by going back to the past we can reveal the future. 


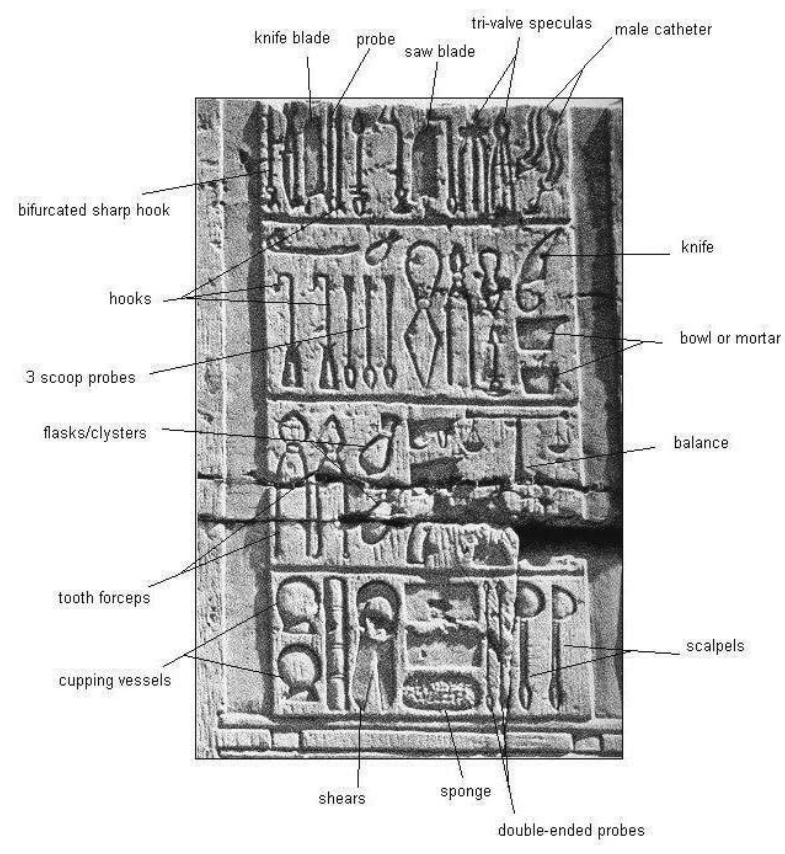

Photo picture 1 - Surgical tools. Relief from outer enclosure wall of the temple Kom Ombo. Available from: http://puffin.creighton.edu/museums/greiner/surgery1.htm

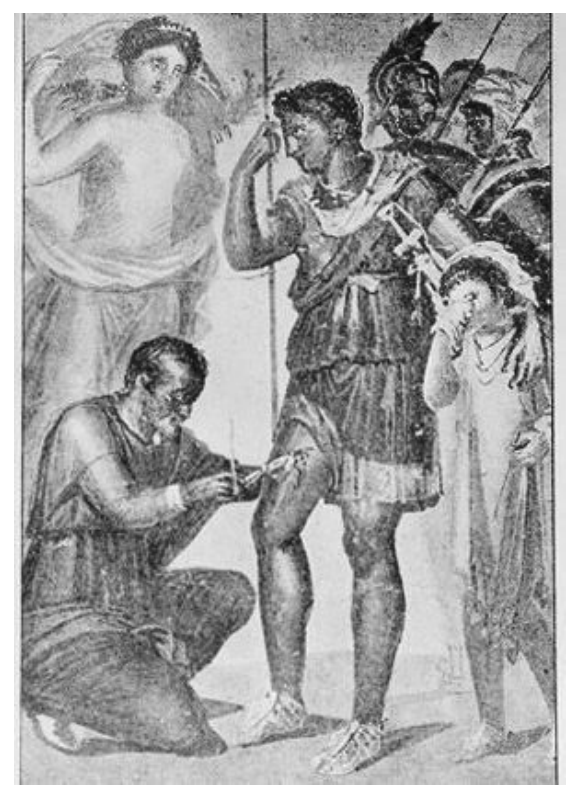

Photo picture 2 - Battlefield surgery. Fresco from Pompei. Allegorical representation of wounded Aeneas, surgeon extracting an arrowhead with forceps. Available from: http:// clendening.kumc.edu/dc/rm/a_197p.jpg 


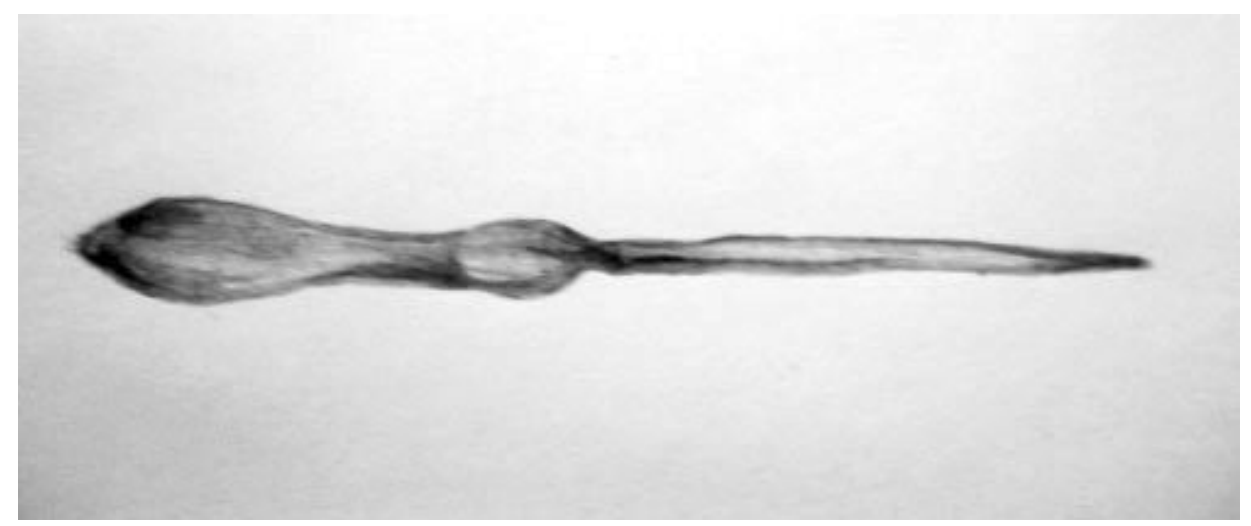

Draw 1 - Spathomela - acus. The National Museum in Belgrade, Collection Dunjic.

Draw 2 - Double purpose instrument (stilus). The National Museum in Belgrade, Collection Dunjic. 


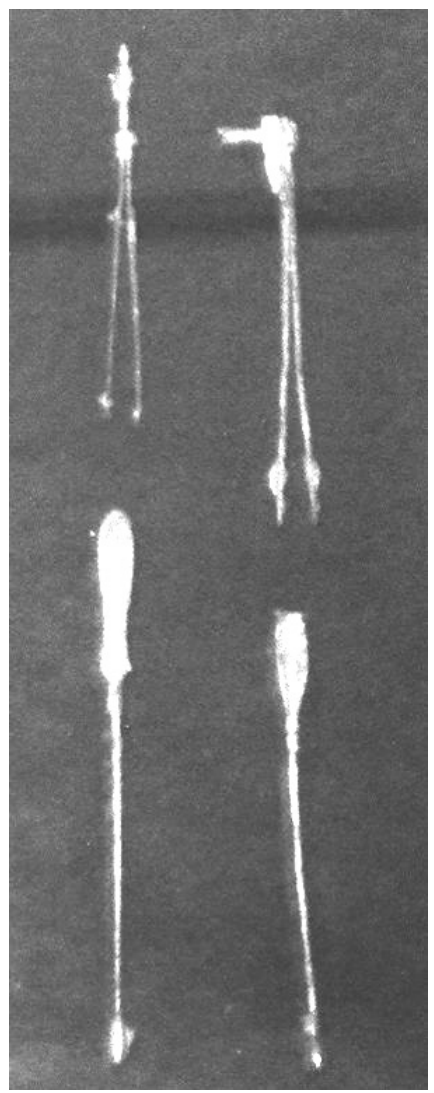

Photo picture 3 - Some of medical instruments escavated from Viminacium. The Museum of the Serbian Medical Society

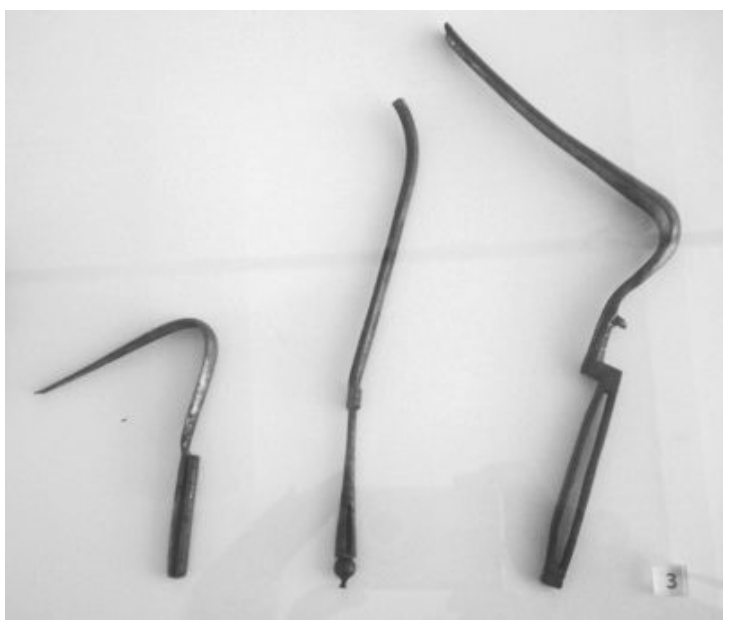

Photo picture 4 - Scrapers. The Museum of the Serbian Medical Society 


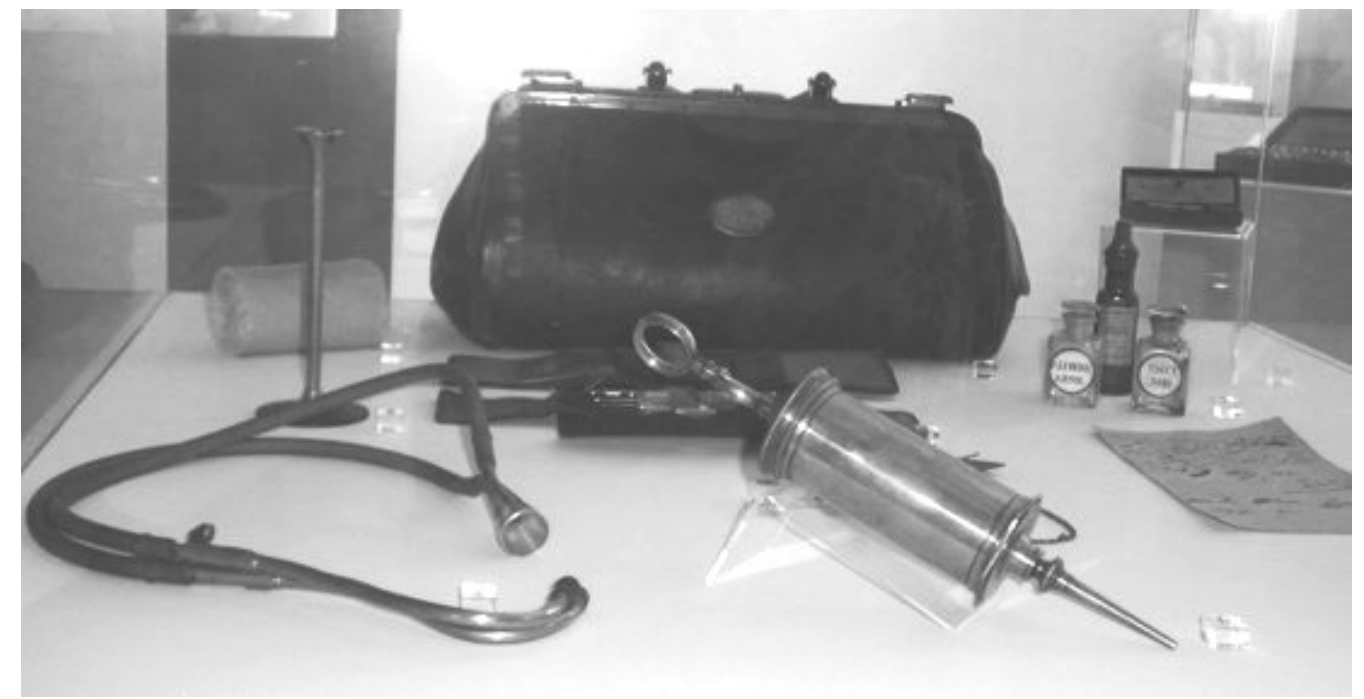

Photo picture 5 - Medical bag from 19 century. The Museum of the Serbian Medical Society

\section{References:}

1. Pavlović B. Od praistorije do savremene medicinske nauke. Annals of Studenica, 9th International Inter University Scientific Meeting [Internet], Academy of Studenica; 2003 (6) [cited 2012 August 5]. Available from: http://www.onk.ns.ac.rs/letopis/Lsa2003/A-1-pavlovic.htm

2. Maksimović J. Uvod u medicinu sa teorijom medicine. Novi Sad: Medicinski fakultet; 2001.

3. Gavela B, Kovačević J, Vasić R, Jovanović V. Arheologija. Beograd: Univerzitet u Beogradu; 1997.

4. Grmek MD, Glesinger L, Dragić M, Pintar I, Levental Z, Dragić Đ. History of medicine. In: Šerger A, editor. Medical encyclopedia. Vol. V. Zagreb: Jugoslovenski leksikografski zavod; 1970. 354-394.

5. Exploring Ancient World Cultures, Readings from the Ancient Near East. Hammurabi's Code of Laws [Internet]. University of Evansville; 1997. 
[cited 2012 August 5]. Available from: http://eawc.evansville.edu/anthology/hammurabi.htm

6. Horstmanshoff HFJ, Stol M, Tilburg CLV, eds. Magic and Rationality in Ancient Near Eastern and Graeco-Roman Medicine. Leiden; Boston: Brill Academic Publication; 2004.

7. Stol M. Epilepsy in Babylonia. Groningen: Styx Publications; 1993.

8. Lyons SA. Medicine in Roman Times. Health Guidance, Medical History [Internet]. Date unknown [cited 2012 August 3]. Available from: http:// www.healthguidance.org/entry/6340/1/Medicine-in-Roman-Times.html

9. University of Virginia Health Sistem [Internet]. Claude Moore Health Sciense Library: Etruscan and Roman Medicine; Date unknown [cited 2012 August 5]. Available from: http://www.hsl.virginia.edu/historical/artifacts/ antiqua/etruscan.cfm

10. Krunić S, editor. Antique bronze from Singidunum. Belgrade: Belgrade City Museum; 1997.

11. Kanic F. Srbija - Zemlja i Stanovništvo [monograph on the Internet]. Scribd. Date unknown [cited 2012 August 5],[about 1017pp.].Available from:http:// www.scribd.com/doc/14428868/F-Kanic-Srbija-Zemlja-i-Stanovnistvo

12. Cvetković-Tomašević G. Arheološki lokalitet na Kosančićevom vencu br. 1216 u Beogradu - neki rezultati sondiranja. Saopštenja. 1981;XIII:177-197.

13. Mirković M. Rimski gradovi na Dunavu u Gornjoj Meziji. Beograd; 1968.

14. Muzej Grada Beograda [Internet]. Medicinski Instrumenti; 2010 [cited 2012 August 4], [1 screen]. Available from: http://www.mgb.org. rs/sr/zbirke/antika/picture/antika/141-medicinski-instrumenti

15. Blic online [Internet]. U moru otkrivena kutija sa tabletama iz rimskog doba; Tanjug 2011 July 10 [cited 2012 August 4]. Available from: http://www. blic.rs/Slobodno-vreme/Zanimljivosti/265077/U-moru-otkrivena-kutijasa-tabletama-iz-rimskog-doba

16. Scribd [Internet]. Fizička Antropologija Rimskog Doba i Ranog Srednjeg veka. Date unknown [cited 2012 August 4], [about 16pp.]. Available from: http://www.scribd.com/doc/ 88554915/Fizicka - Antropologija-Rimskog-Doba-i-Ranog-Srednjeg-V

17. Krunić S. Rimski skalpeli i drugi hirurški instrumenti iz gornje mezije. Annals of Studenica, 9th International Inter University Scientific Meeting [Internet], Academy of Studenica; 2003(6) [cited 2012 August 5]. Available 
from: http://www.onk.ns.ac.rs/letopis/Lsa2003/A-3-krunic.htm

18. University of Virginia Health Sistem [Internet]. Claude Moore Health Sciense Library: Surgical Instruments from Ancient Rome; Date unknown [cited 2012 August 4]. Available from: http://www.hsl.virginia.edu/histori$\mathrm{cal} /$ artifacts/antiqua/instruments.cfm

19. Narodni Muzej [Internet]. Zbirka Dunjić; 2010 [cited $2012 \mathrm{Au}-$ gust 5], [1 screen]. Available from: http://www.narodnimuzej. rs/zbirke/zbirke-narodnog-muzeja/antika/zbirka-dunjic/

20. Narodni Muzej [Internet]. Zbirka Kosmaj; 2010 [cited $2012 \mathrm{Au}-$ gust 5], [1 screen]. Available from: http://www.narodnimuzej. rs/zbirke/zbirke-narodnog-muzeja/antika/zbirka-kosmaj/

21. Glumac M. Antički Kosmaj. Sopot: Centar za kulturu; 2009.

22. Mikić Ž. Trepanacija lobanja na Antičkom Viminacijumu - Antropološke informacije. Arheologija i prirodne nauke [Internet]. 2006 [cited $2012 \mathrm{Au}-$ gust 2]; 1:9-14. Available from: http://www.viminacium.org.rs/ELibrary/ arch_sci/Volume_1/index.html?language=srpski\&pagenum $=7$ \&pngsize $=1$

23. Spasić-Đurić D. Grob Lekara iz Viminacijuma/Medical Doctor's Crypt in Viminacium.Timočki Medicinski Glasnik [Internet]. 2004 [cited $2012 \mathrm{Au}-$ gust 5]; 29(1):24-26. Available from: http://www.tmg.org.rs/v29s128.htm

24. Muzej Nauke i Tehnike - Odeljenje Muzej Srpskog lekarskog društva [Internet]. [cited 2012 August 5], [1 screen]. Available from: http://www. muzejnt.rs/en/490

25. Pejić M. Blic online -Pogledajte eksponate: Medicina u Srbiji kroz vekove [Internet]. 2012 [cited 2012 Avgust 5], [1 screen] Available from: http:// www.blic.rs/Vesti/Drustvo/314330/Pogledajte-eksponate-Medicina-uSrbiji-kroz-vekove

26. Muzej Nauke i Tehnike, Collection of Medical Technology [Internet]. [cited 2012 August 5], [1 screen]. Available from: http://www.muzejnt.rs/en/245 


\section{Rezime}

U uvodnom delu rada razmatra se istorijski razvoj medicine objašnjavajući da se počeci medicinske prakse mogu pratiti na nekoliko načina: putem pisanih izvora, preko vizuelnih predstava (slika) kao i posredstvom pronađenih medicinskih predmeta.

Dalje u tekstu pretstavljaju se medicinski instrumenti datovani između I i IV veka i razmatra se medicinska praksa na teritoriji nekadašnjih rimskih provincija Gornje Mezije i Panonije, kao i u okolini Singidunuma i Kosmaja. Nakon toga prikazani su medicinski aparati i predmeti iz skorije istorije, od kojih su neki propraćeni i vizuelnom dokumentacijom kao što su slike i crteži.

Glavni cilj rada bio je da se predstave postojeći medicinski instrumenti i predmeti koji se nalaze u okviru kolekcija beogradskih muzeja. Shodno tome, prikazane su zbirke iz pet muzeja, a pojedini predmeti su detaljnije obrađeni.

Poslat: 8. 2.2013.

Recenziran: 12. 4. 2013.

Prihvaćen: 17. 5. 2013. 